\title{
Geographic and seasonal distribution of the infective stage of Ceratomyxa shasta (Myxozoa) in Northern California
}

\author{
Gary L. Hendrickson ${ }^{1}$, Annelise Carleton ${ }^{1}$, Donald Manzer ${ }^{2}$ \\ ${ }^{1}$ Department of Fisheries and Telonicher Marine Laboratory, Humboldt State University, Arcata, California 95521, USA \\ ${ }^{2}$ California Department of Fish and Game, Fish Disease Laboratory, 2111 Nimbus Road, Rancho Cordova, California 95670, \\ USA
}

\begin{abstract}
The geographic distribution of the infective stage of Ceratomyxa shasta (in California USA) is limited to the San Joaquin, Sacramento, Pit, and Klamath river systems. In the San Joaquin system, the infective stage occurs in the Mokelumne River. In the Sacramento system, the infective stage occurs in the mainstem of the Sacramento River as well as in some major tributaries (Feather River, Butte Creek). In the Klamath system, only the mainstem of the Klamath River is infective. The occurrence of infective C. shasta in the Klamath River is seasonal. During 1986-1987, the river was infective until December 5 to 15 (water temperature $7^{\circ} \mathrm{C}$ ). The river was non-infective until spring of 1987. Infectivity reoccurred on April 9 to 20 (water temperature $15^{\circ} \mathrm{C}$ ).
\end{abstract}

\section{INTRODUCTION}

Ceratomyxosis is a disease of trout and salmon in the Pacific northwest caused by the myxozoan Ceratomyxa shasta Noble, 1950. Ceratomyxosis has caused disease and deaths in hatchery and wild salmonids, both juvenile and adult (Rucker et al. 1954, Wales \& Wolf 1955, Conrad \& DeCew 1966, Schafer 1968, Sanders et al. 1970, Sanders et al. 1972, Ratliff 1981, Buchanan et al. 1983). Salmonid species and strains vary widely in susceptibility to ceratomyxosis (Schafer 1968, Johnson 1975, Zinn et al. 1977, Ratliff 1981. Buchanan et al. 1983, Ching 1984, Ching \& Munday 1984b). Within a species or strain susceptibility may vary from highly susceptible to resistant.

The life cycle of Ceratomyxa shasta is not completely known. In particular, the stage infective to fish is unknown even though its ecology and infection process have been studied. The geographic distribution of C. shasta is limited to northern California, Oregon, Washington, Idaho, and British Columbia (Johnson et al. 1979, Ching \& Munday 1984a). Within its geographic range, only certain waters contain the stage infective to fish (infective stage). Other waters may contain infected salmonids but lack the infective stage (Sanders et al. 1970, Johnson 1975, Johnson et al. 1979). Little work has been done on the geographic distribution of the infective stage of $C$. shasta in California (Table 1). Nothing has been reported concerning rivers tested but negative for the infective stage.

The infection process is seasonal and is generally limited to about May to November (Schafer 1968, Johnson 1975, Udey et al. 1975, Johnson et al. 1979, Ratliff 1983, Ching \& Munday 1984a). However, seasonal occurrence in California has been examined only at the Crystal Lake Hatchery in the Pit River drainage (Schafer 1968). At Crystal Lake, infection did not occur at temperatures less than $10^{\circ} \mathrm{C}$. January, February, and March were non-infective depending on water temperature. California rivers and streams with anadromous fish runs have not been studied in this regard. At warmer temperatures, the course of the disease is faster (Udey et al. 1975).

There is no known treatment for ceratomyxosis hence prevention and management are paramount. Management involves stocking resistant species or strains wherever waters are known to harbor the infective stage, and releasing hatchery fish during periods of low or no infectivity. The objectives of this study were to determine the geographic and seasonal occurrence of the infective stage of Ceratomyxa shasta in California. Such information is essential to management of resident and anadromous salmonids. 
Table 1 Cerato myxa shasta. (iographic distribution of the infective stage in California

\begin{tabular}{|c|c|c|}
\hline Location and watershed & Comments & Source \\
\hline Sacramento River, Shasta Lake & $\begin{array}{l}\text { Upstream from mouth to and including } \\
\text { Shasta Lake }\end{array}$ & $\begin{array}{l}\text { Wolf \& Manzer unpubl. (cited in Johnson } \\
\text { et al. 1979) }\end{array}$ \\
\hline Feather River & $\begin{array}{l}\text { Downstream from Oroville to confluence } \\
\text { with Sacramento River }\end{array}$ & $\begin{array}{l}\text { Wolf \& Manzer unpubl. (cited in Johnson } \\
\text { et al. 1979) }\end{array}$ \\
\hline Pit River & $\begin{array}{l}\text { Between Sucker Springs and confluence } \\
\text { with Fall River }\end{array}$ & Schafer (1968) \\
\hline $\begin{array}{l}\text { Crystal, Baum, Rising River } \\
\text { and Britton Lakes }\end{array}$ & Probably throughout each & Schafer (1968) \\
\hline Rising River & Throughout river & Shafer (1968) \\
\hline Hat Creek & Below Baum Lake & Shafer (1968) \\
\hline Fall River & Probably entire river & Schafer (1968) \\
\hline Klamath River & $\begin{array}{l}\text { Upstream from mouth to and including } \\
\text { Klamath Lake in Oregon }\end{array}$ & Johnson et al. (1979) \\
\hline
\end{tabular}

\section{MATERIAL AND METHODS}

Shasta rainbow trout used as sentinels (and highly susceptible to Ceratomyxa shasta) were obtained from California Department of Fish and Game's (CDFG) Mount Shasta Hatchery or American River Hatchery, USA. Fish were held at the Humboldt State University (HSU) Hatchery or CDFG Fish Disease Laboratory until needed for field exposures.

Geographic distribution of the infective stage of Ceratomyxa shasta was determined by placing caged sentinels in test streams and rivers. When a river system was first tested, cages were placed near the mouth of the system but above tidal influence. Further exposures in the same system were performed only if the infective stage was present and were always performed further up river. Plastic minnow traps (43.5 long $\times 23 \mathrm{~cm}$ wide) with entrance holes plugged or collapsible wood and plastic mesh cages $(1.0 \times 1.0 \times 1.0 \mathrm{~m})$ were used for field exposures. Up to 25 fish (depending on size) were placed in minnow trap-type cages. Up to 100 fish were placed in larger cages. Caged sentinels were left in test streams for 10 to $14 \mathrm{~d}$ to allow for infection to take place. Sentinels were not fed during exposure. Sentinels were then returned to the HSU Telonicher Marine Laboratory or CDFG Fish Disease Laboratory for rearing.

Field exposures, to determine seasonal occurrence of the infective stage of Ceratomyxa shasta, were carried out in the Klamath River at Klamath GIen, California, during the winter of 1986-1987 This portion of the river is highly infective. Twenty caged sentinels were placed in the river for $10 \mathrm{~d}$ at $10-\mathrm{d}$ intervals. Only minnow trap-type cages were used for seasonal studies. Sentinels were not fed during exposure. River water temperature was monitored throughout the study. Sentinels were brought to the HSU Telonicher Marine Laboratory for rearing.

Sentinels from geographic and seasonal studies were reared for at least $70 \mathrm{~d}$ or until ceratomyxosis was diagnosed. This rearing period allowed for development of the characteristic spores of Ceratomyxa shasta. Rearing was performed at the HSU Telonicher Marine Laboratory or at CDFG Fish Disease Laboratory. Individual lots of fish were kept separate at all times. Each lot was maintained in a self-contained rearing unit (tank and filter) or on a separate water supply to prevent cross contamination. Sentinel fish were fed a maintenance ration throughout rearing.

Sentinel fish were examined for ceratomyxosis either when they died or after 70 or more d rearing. A small piece of lower intestine was removed from each fish and 2 wet mounts prepared from the fluid contents. Each wet mount was examined at $400 \times$ or $1000 \times$ for 10 min or until spores were observed. Diagnosis of ceratomyxosis was based on recovery of the characteristic kidney bean-shaped spores of Ceratomyxa shasta.

\section{RESULTS}

We found the infective stage of Ceratomyxa shasta in the San Joaquin, Sacramento, and Klamath River systems (Table 2). In the San Joaquin system, the infective stage occurs in the Mokelumne River. In the Sacramento system, the infective stage occurs in the mainstem of the Sacramento River as well as some of the major tributaries (Feather River, Butte Creek). In the Klamath system, only the mainstem of the Klamath 
Table 2. Ceratomyxa shasta. Sites tested for presence of infective stage; map locations; and results. Map locations refer to range (R), township (T), and section (S) on U. S. Geological Survey topographic maps. Pos: infective stage detected by sentinel fish; Neg: negative

\begin{tabular}{|c|c|c|}
\hline Test site & Map location & Result \\
\hline \multicolumn{3}{|l|}{ Coastal rivers } \\
\hline Smith River & R1E, T17N, S32 & Neg \\
\hline Praire Creek & R1E, T11N, S22 & Neg \\
\hline Redwood Creek & R1E, T10N, S11 & Neg \\
\hline Mad River & R2E, T6N, S31 & Neg \\
\hline Eel River & R1W, T3N, S29 & Neg \\
\hline Mattole River & R2W, T2S, S9 & Neg \\
\hline Ten-Mile River & R17W, T20N, S34 & Neg \\
\hline Noyo River & $\mathrm{R} 17 \mathrm{~W}, \mathrm{~T} 18 \mathrm{~N}, \mathrm{~S} 1$ & Neg \\
\hline Big River & R17W, T17N, S24 & Neg \\
\hline Navarro & R16W, T15N, S7 & Neg \\
\hline Gualala River & R15W, T11N, S26 & Neg \\
\hline Russian River & R11W, T7N, NE 1/4 sec (at Duncans Mills) & Neg \\
\hline \multicolumn{3}{|l|}{ Klamath-Trinity system } \\
\hline Klamath River at Klamath Glen & R2E, T13N, S 19 (river mile 7) & Pos \\
\hline at Weitchpec & R4E, T9N, S10 (river mile 43.5) & Pos \\
\hline above Salmon River & R6E, T12N (river mile 71 ) & Pos \\
\hline at Beaver Creek & R8W, T46N, S6 (river mile 161 ) & Pos \\
\hline above Scott River & R10W, T46N, S32 (river mile 144) & Pos \\
\hline at Iron Gate Hatchery & R5W, T47N, S17 (river mile 189.5) & Pos \\
\hline at Copco Lake & R4W, T48N, S35 (river mile 202) & Pos \\
\hline Trinity River at Weitchpec & R4E, T9N, S10 (river mile 0) & Neg \\
\hline at Willow Creek & R5E, T7N, S28 (river mile 25.5 ) & Neg \\
\hline at Big Bar & R12W, T33N, S6 (river mile 63.5) & Neg \\
\hline Salmon River & R6E, T11N, S2 & $\mathrm{Neg}$ \\
\hline Scott River & R10W, T45N, S21 & Neg \\
\hline Shasta River & R6W, T45N, S29 & $\mathrm{Neg}$ \\
\hline Bogus Creek & R5W, T47N, S13 & $\mathrm{Neg}$ \\
\hline Humbug Creek & R7W, T46N, S16 & Neg \\
\hline \multicolumn{3}{|l|}{ Sacramento river system } \\
\hline Sacramento River at Los Molinos & R2W, T25N (river mile 229) & Pos \\
\hline Sacramento River just above Keswick Dam & R5W, T32N, S21 (river mile 302.5) & Pos \\
\hline Sacramento River above Shasta Lake & R5W, T36N, S15 & Neg \\
\hline Feather River (between Yuba City/Marysville) & R3E, T15N (river mile 29) & Pos \\
\hline Lake Almanor & R7E, T27-28N; R8E, T27-28N & Neg \\
\hline Butt Valley Reservoir & $R 7 E_{1} T 26-27 N$ & Neg \\
\hline Antelope Reservoir & R12E, T27N, S15, 22-26 & Neg \\
\hline Spanish Creek (tributary to East Branch NF) & R9E, T25N, S22 & Neg \\
\hline East Branch North Fork Feather River & R7E, T25N, S21 & $\mathrm{Neg}$ \\
\hline North Fork Feather River at Belden Reservoir & R7E, T26N, S25 & Pos \\
\hline North Fork Feather River at Rock Creek Reservoir & R6E, T25N, S26 & Pos \\
\hline $\begin{array}{l}\text { Milk Ranch Creek ( } 1 / 2 \text { mile above confluence with NF } \\
\text { Feather River) }\end{array}$ & R6E, T24N, S2 & Neg \\
\hline Bear River & R5E, T13N, S2 & Neg \\
\hline Butte Creek & R1W, T16N, S35 & Pos \\
\hline \multicolumn{3}{|l|}{ San Joaquin river system } \\
\hline North Mokelumne River & R4E, T4N (river mile 9) & Pos \\
\hline
\end{tabular}

River is infective. Coastal rivers lack the infective stage.

In winter 1986, the Klamath River was infective up to and including the exposure interval from December 5 to 15 . At this time the water temperature was $7^{\circ} \mathrm{C}$. The river was not infective until the spring of 1987 . Sentinels were first infected during the exposure interval from April 9 to 20,1987 at a water temperature of $15^{\circ} \mathrm{C}$.

\section{DISCUSSION}

The known distribution of the infective stage of Ceratomyxa shasta in California is shown in Fig. 1 Rivers or streams which tested negative via sentinels for the presence of the infective stage are also included. The figure is based on Schafer (1968), Wolf \& Manzer as reported by Johnson et al. (1979), and on this study. 


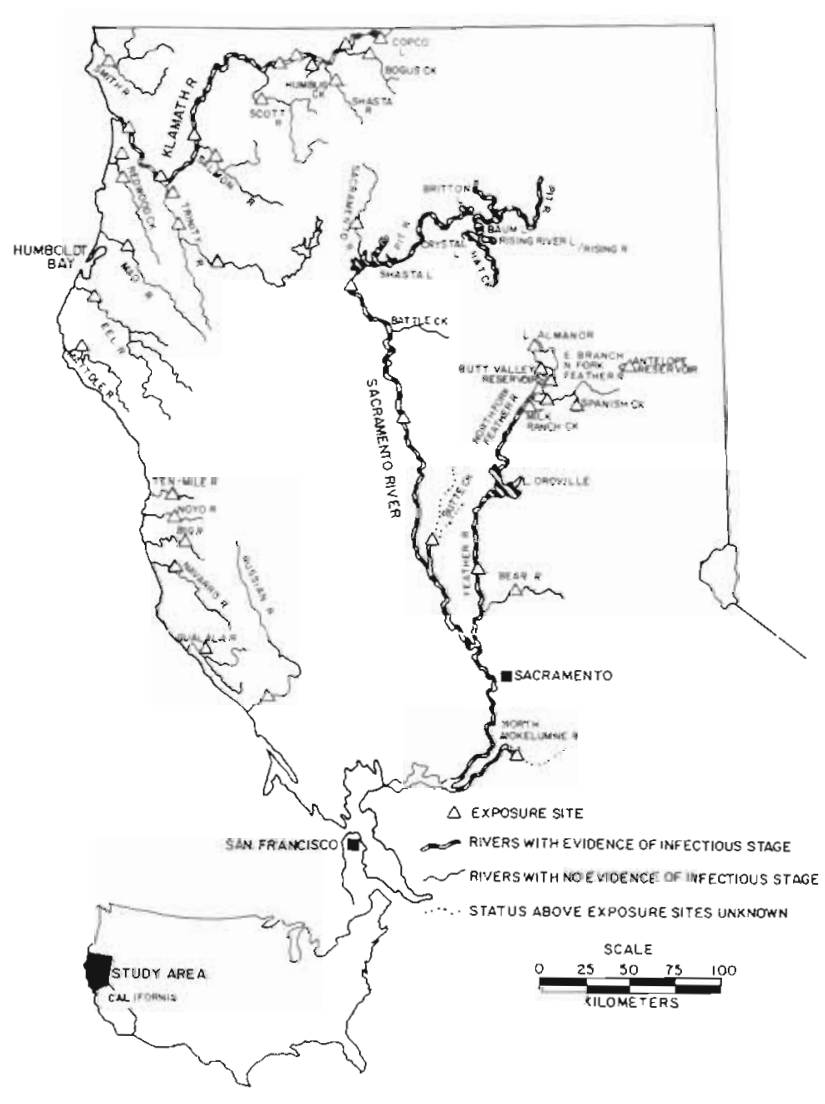

Fig. 1. Ceratomyxa shasta. Known geographic distribution of the infective stage in California. Includes all known sources

In 1 instance another source was used. Horsch (1986, U.S. Fish and Wildlife Service, Coleman National Fish Hatchery, Anderson, California, pers. comm.) planted caged sentinels in Battle Creek (Sacramento Drainage) to demonstrate non-infectivity in these waters.

The distribution of the infective stage of Ceratomyxa shasta in California is limited to the San Joaquin, Sacramento, Klamath, and Pit River system. The Sacramento and Klamath are two of the most important salmon and steelhead production areas in California. The Pit River system includes many of California's blue ribbon trout streams (e.g. Hat Creek, Fall River, Rising River)

Susceptible salmonids may be subjected to high mortalities during outmigration through infective waters or following stocking into infective waters. Therefore, no fish should be released into infective waters until their susceptibility to ceratomyxosis has been assessed. The California Department of Fish and Game's current policy is to release infected anadromous stocks only to those infective waters where the parent stock originated. Resident trout production is restricted to noninfective waters since current policy would generally not permit release of infected stocks even into infective waters.
The reason(s) for the limited distribution of the infective stage of Ceratomyxa shasta is unknown. However, the patchiness of the distribution might reflect distribution of an intermediate host. This patchiness of distribution suggests fairly specific ecological requirements for the infective stage. Thus, accidental introductions of this pathogen would seem unlikely Nevertheless transfer of fish from infective to noninfective waters is, at best, unwise.

The seasonal distribution of the infective stage of Ceratomyxa shasta in the Klamath River appears similar to that reported by Schafer (1968) at Crystal Lake Hatchery. However, it seems likely that given the appropriate temperatures and water flow regimes, the Klamath could be infective at any time of year. The Fldsel Riveı, British Columbiá, Cañada, can be infective at temperatures as low as 4 to $6^{\circ} \mathrm{C}$ (Ching \& Munday 1984a). Hatchery releases should, however, be timed so as to minimize contact between fish and infective waters. This means outmigrants should contact infective waters as early in the spring or as late in the fall as possible. In particular late spring releases of age-0 chinook that must contact infective waters should be avoided. In response to ceratomyxosis in Lake Simtustus and the Deschutes River, Oregon Department of Fish and Wildlife releases into these waters only age-1 spring chinook smolts that outmigrate before $C$. shasta infectivity begins in late spring (Ratliff 1981). Such a program should prove useful in California also.

Acknowledgements. We thank the staff of the Telonicher Marine Laboratory, especially Lee Rusconi and Dave Hoskins for aid in rearing fish. Various personnel of the California Department of Fish and Game and U.S. Fish and Wildlife Service helped in several aspects of the project. We are particularly grateful to Tony Nevison, CDFG Mt Shasta Hatchery, and Don Evins, CDFG American River Hatchery, for providing sentinel Shasta rainbow trout. This work is a result of research sponsored in part by NOAA, National Sea Grant College Program, Department of Commerce, under grant number NA85NA-D-SG140, project number R/F-105, through the California Sea Grant College Program, and in part by the California State Resources Agency. The U.S. Government is authorized to reproduce and distribute for governmental purposes.

\section{LITERATURE CITED}

Buchanan, D. V., Sanders, J. E., Zinn, J. L., Fryer, J. L. (1983) Relative susceptibility of four strains of summer steelhead to infection by Ceratomyxa shasta. Trans. Am. Fish. Soc. 112: $541-543$

Ching. H. L. (1984). Comparative resistance of Oregon (Big Creek) and British Columbia (Capilano) Juvenile chinook salmon to the myxozoan pathogen, Ceratomyxa shasta, after laboratory exposure to Fraser River water. Can. J. Zool. 62: 1423-1424 
Ching, H. L., Munday, D. R. (1984a). Geographic and seasonal distribution of the infectious stage of Ceratomyxa shasta Noble, 1950, a myxozoan salmonid pathogen in the Fraser River system. Can. J. Zool. 62: 1075-1080

Ching, H. L., Munday, D. R. (1984b). Susceptibility of six Fraser chinook salmon stocks to Ceratomyxa shasta and the effects of salinity on ceratomyxosis. Can. J. Zool. 62: 1081-1083

Conrad, J. F., Decew, M. (1966). First report of Ceratomyxa in juvenile salmonids in Oregon. Prog. Fish Cult. 28: 238

Johnson, K. A. (1975). Host susceptibility, histopathologic, and transmission studies on Ceratomyxa shasta, a myxosporidan parasite of salmonid fish. Ph. D. Dissertation, Oregon State Univ, Corvallis

Johnson, K. A., Sanders, J. E., Fryer, J. L. (1979). Ceratomyxa shasta in salmonids. U.S. Fish Wildl. Serv., Fish Dis. Leafl. No. 58. Washington D.C.

Ratliff, D. E. (1981). Ceratomyxa shasta: Epizootiology in chinook salmon of central Oregon. Trans. Am. Fish. Soc. 110: $507-513$

Ratliff, D. E. (1983). Ceratomyxa shasta: Longevity, distribution, timing and abundance of the infective stage in central Oregon. Can. J. Fish. aquat. Sci. 40: 1622-1632

Rucker, R. R., Earp, B. J., Ordal, E. J. (1954). Infectious dis-

Responsible Subject Editor: Professor W. Körting, Hannover, F.R. Germany eases of Pacific salmon. Trans. Am. Fish. Soc. 83: 297-312 Sanders, J. E., Fryer, J. L., Gould, R. W. (1970). Occurrence of the myxosporidan parasite Ceratomyxa shasta, in salmonid fish from the Columbia River basin and Oregon coastal streams. In: Snieszko, S. F. (ed.) A symposium on diseases of fishes and shellfishes. Am. Fish. Soc. Spec. Publ. 5. Bethesda, MD, p. 133-141

Sanders, J. E., Fryer, J. L., Leith, D. A., Moore, K. D. (1972) Control of the infectious protozoan Ceratomyxa shasta by treating hatchery water supplies. Prog. Fish Cult. 34 $13-17$

Schafer, W. E. (1968). Studies on the epizootiology of the myxosporidan Ceratomyxa shasta Noble. Calif. Fish Game 54: $90-99$

Udey, L. R., Fryer, J. L., Pilcher, K. S. (1975). Relation of water temperature to ceratomyxosis in rainbow trout (Salmo gairdneri) and coho salmon (Oncorhynchus kisutch). J. Fish. Res. Bd Can. 32: 1545-1551

Wales, J. H., Wolf, H. (1955). Three protozoan diseases of trout in California. Calif. Fish Game 41 183-187

Zinn. J. L., Johnson, K. A., Sanders, J. E., Fryer, J. L. (1977). Susceptibility of salmonid species and hatchery strains of chinook salmon (Oncorhynchus tshawytscha) to infections by Ceratomyxa shasta. J. Fish. Res. Bd Can. 34: 933-936

Manuscript first received: June 9, 1989

Revised version accepted: August 14, 1989 